\title{
ESTUDO DE ASSOCIAÇÃO ENTRE O POLIMORFISIMO SERINA-9-GLICINA DO RECEPTOR DOPAMINÉRGICO D3 E ESQUIZOFRENIA
}

\author{
Quirino Cordeiro Júnior', Ricardo Junqueira², Homero Vallada ${ }^{3}$
}

\begin{abstract}
RESUMO - Duas abordagens genético-moleculares foram realizadas para investigar a possível associação entre o polimorfismo serina-9-glicina no receptor dopaminérgico D3 e esquizofrenia. Na primeira análise, um grupo de 141 pacientes com esquizofrenia foi comparado a um grupo-controle de 189 indivíduos pareado para sexo e origem étnica. No outro estudo, foi realizada análise de 35 trios (pai e mãe não afetados e paciente com esquizofrenia). Os resultados desses estudos não apresentaram associação alélica ou genotípica estatisticamente significante com esquizofrenia. Pode-se concluir que o polimorfismo serina-9-glicina no receptor dopaminérgico D3 não é um fator de risco para desenvolver esquizofrenia na população estudada.
\end{abstract}

PALAVRAS-CHAVE: receptor dopaminérgico D3, polimorfismo genético, associação genética, esquizofrenia.

\begin{abstract}
Study of association between the ser-9-gly polymorphism of the D3 dopaminergic receptor and schizophrenia

ABSTRACT - Two molecular genetic studies were undertaken to investigate the association between a ser-9-gly polymorphism in the dopamine D3 receptor gene and schizophrenia. The first study analysed 141 schizophrenic patients and 189 matched controls. In addition, an haplotype relative risk study was performed using 35 trios (mother, father, affected offspring). No allelic or genotype association was found in both studies. We conclude that this D3 polymorphism is not a risk factor for schizophrenia in our sample.
\end{abstract}

KEY WORDS: dopamine D3 receptor, genetic polymorphism, genetic association, schizophrenia.

A hipótese dopaminérgica envolvida na fisiopatologia da esquizofrenia vem do fato dos antipsicóticos exercerem sua ação bloqueando os receptores de dopamina. Os receptores dopaminérgicos do tipo D2 foram os primeiros a serem reconhecidos como alvos dos antipsicóticos clássicos ${ }^{1}$. Entretanto, outros receptores dopaminérgicos, como o $\mathrm{D}^{2}$, passaram a ser envolvidos nos mecanismos de ação dos antipsicóticos, evidenciando um provável papel na fisiopatologia da esquizofrenia'. Estudos "in vivo" em cobaias, mostraram que o uso de antipsicóticos, tanto os clássicos como os de nova geração, elevam os níveis intraneuronais de mRNA do receptor $\mathrm{D}^{3}$.

A localização preferencial desses receptores no sistema nervoso central pode fornecer indícios acerca de seu papel em alguns transtornos mentais. Os receptores D3 estão predominantemente localizados no sistema límbico, e sabe-se que algumas alte- rações cognitivas e afetivas presentes em pacientes com esquizofrenia estão relacionadas a disfunções nesse sistema. Assim, tal receptor surge como um dos candidatos para desempenhar papel importante na fisiopatologia da esquizofrenia ${ }^{4}$.

Estudos genéticos recentes envolvendo o receptor D3 têm focado uma mudança de aminoácidos que ocorre em sua porção extracelular ${ }^{5}$. Uma mudança nucleotídica de alanina (A) por guanina (G) resulta em substituição de aminoácido (serina por glicina) na posição 9 da proteína (receptor D3). Não há evidências de que esse polimorfismo do receptor D3 afete a ação de drogas antipsicóticas, nem o processo de transdução, porém tal alteração poderia influenciar sua inserção na membrana neuronal ${ }^{5}$.

O primeiro estudo de associação entre o polimorfismo alélico serina-9-glicina no gene do receptor D3 mostrou um excesso de homozigose (alelos iguais)

Laboratório de Neurociências (LIM-27) do Instituto de Psiquiatria do Hospital das Clínicas (HC) da Faculdade de Medicina da Universidade de São Paulo (FMUSP): ${ }^{1}$ Médico-Residente do Instituto de Psiquiatria do HC-FMUSP; ${ }^{2}$ Pós-Graduando do Departamento de Fisiopatologia Experimental da FMUSP; ${ }^{3}$ Professor Associado do Departamento de Psiquiatria da FMUSP. Apoio FAPESP processos números 97/110830 e 99/122205-7. 
quando comparados pacientes com esquizofrenia e controles $(p=0,0001)$, em uma população combinada de caucasianos da França e País de Gales ${ }^{6}$. Estudos posteriores realizados em populações caucasianas $^{7-16}$ e asiáticas ${ }^{17-22}$ tentaram replicar esse achado, porém sem sucesso. Por outro lado, Shaikh et al. ${ }^{23}$ e Spurlock et al. ${ }^{24}$, em estudo multicêntrico europeu (European Multicentre Association Study of Schizophrenia), encontraram associação entre o polimorfismo alélico em questão e esquizofrenia. Três estudos de meta-análise também demonstraram essa associação ${ }^{23,25,26}$.

Outros estudos têm encontrado associações entre o polimorfismo alélico serina-9-glicina e algumas populações específicas de esquizofrênicos. Nimgoankar et al. ${ }^{7}$ demonstraram associação entre esquizofrenia em pacientes com história familiar desse transtorno e homozigose para o alelo que dá origem à serina na posição 9 do receptor D3 (genótipo 1-1). Jönsson et al. ${ }^{9}$ e Scharfetter et al. ${ }^{27}$ encontraram um excesso dessa mesma homozigose em esquizofrênicos bons respondedores a antipsicóticos, enquanto Mant et al..$^{12}$ demonstraram um excesso também dessa homozigose em esquizofrênicos bons respondedores a antipsicóticos, com história familiar desse transtorno e do sexo masculino. Krebs et al. ${ }^{28}$ encontraram associação em esquizofrênicos que faziam uso de drogas no passado, e Steen et al. ${ }^{29} \mathrm{e}$ Basile et al. ${ }^{30} \mathrm{em}$ pacientes que desenvolveram discinesia tardia.

Alguns autores têm estudado uma possível associação entre esse polimorfismo genético e outros transtornos psiquiátricos. Shaikh et al. ${ }^{31}$ não conseguiram estabelecer associação desse polimorfismo com transtorno afetivo bipolar. Dikeos et al. ${ }^{32}$ encontraram associação entre o alelo 2 (glicina-9) e depressão. Mais recentemente, o receptor D3 também vem sendo estudado em pacientes dependentes de cocaína ${ }^{33}$.

Os estudos realizados até o momento para verificar a associação entre o polimorfismo serina-9glicina no receptor D3 e esquizofrenia foram do tipo caso-controle. Essa modalidade de estudo pode apresentar resultados falso-positivos (erro tipo I), caso o grupo-controle não seja pareado adequadamente no que tange à origem étnica, pois a frequência alélica varia de uma etnia para outra. Uma estratégia recente para evitar o erro tipo I é a realização de estudos com trios, já que o genótipo dos pacientes são originados através da distribuição aleatória dos alelos de seus pais, logo a identificação de um determinado alelo associado com a doença seria aquele pre- sente no paciente em uma frequência maior que aquela esperada por acaso. Assim, no presente trabalho serão realizados os dois tipos de estudos genético-moleculares, investigando uma possível associação entre esquizofrenia e o polimorfismo serina9-glicina no gene do receptor D3, tratando-se do primeiro estudo utilizando uma amostra brasileira.

\section{MÉTODO}

\section{SUJEITOS}

Todos os sujeitos que participaram dos estudos foram previamente informados sobre a pesquisa, e logo após assinavam um termo de consentimento (os estudos foram aprovados pela Comissão de Ética para Análise de Projetos de Pesquisa - CAPPesq da Diretoria Clínica do Hospital das Clínicas e da Faculdade de Medicina da Universidade de São Paulo).

\subsection{Estudo de caso-controle (associação)}

A) Grupo de pacientes - Um total de 141 pacientes com diagnóstico de esquizofrenia, de acordo com a Classificação Internacional da Doenças ( $10^{\text {a }}$ edição) (CID-10), de origem étnica distinta, de ambos os sexos, foi recrutado dos ambulatórios e enfermarias do Instituto de Psiquiatria do Hospital das Clínicas da Faculdade de Medicina da Universidade de São Paulo (IPq HC-FMUSP).

B) Grupo-controle - Um grupo controle pareado por sexo, idade e origem étnica foi constituído de 189 pessoas, recrutadas no Banco de Sangue do HC-FMUSP.

\subsection{Estudo com trios}

Foram selecionados 35 trios (pai e mãe não afetados, filho com esquizofrenia, segundo os critérios da CID-10). Os pacientes que compunham esses trios eram acompanhados nos ambulatórios e enfermarias do IPq-FMUSP e não faziam parte da amostra de pacientes do estudo de caso-controle.

\section{ANÁLISE DO DNA}

O DNA das pessoas que participaram do estudo foi extraído dos linfócitos obtidos a partir de uma amostra de seu sangue venoso periférico, seguindo procedimento padrão (kit para extração de DNA Nucleon II, Scotlab). A região do gene que codifica o receptor dopaminérgico do subtipo D3 e que contém o polimorfismo serina-9-glicina foi amplificada através da reação em cadeia da polimerase (PCR), de acordo com as condições descritas por Lannfelt et al (1992). O primer usado para a realização do PCR foi 5'GCTCTATCTCCAACTCTCACA 3' (sense) e 5'AAGTCTACTCACCTCCAGGTA 3' (anti-sense). O PCR foi realizado em um volume total de $20 \mu \mathrm{l}$, contendo $25 \mathrm{ng}$ de DNA genômico, $5 \mathrm{pmol}$ de cada oligonucleotídeo do primer , 1,5 mM de $\mathrm{MgCl}_{2}, 50 \mathrm{mM}$ de $\mathrm{KCl}, 10 \mathrm{mM}$ de TRIS-HCl em pH 8,3, 0,2 mM de dNTPs (Amersham) e 0,5 UTaq DNA polimerase (ampli Taq, Perkin-Elmer Cetus).Os 
Tabela. Distribuição dos alelos e dos genótipos do polimorfismo Serina-9-Glicina.

\begin{tabular}{lccc}
\hline & Controles (\%) & Esquizofrênicos (\%) & $p$ \\
\hline $\begin{array}{l}\text { Alelo } \\
\text { Serina (S) }\end{array}$ & $209(57)$ & $169(60)$ & \\
& & $113(40)$ & \\
Glicina (G) & $157(43)$ & & \\
Genótipo & & $56(39,7)$ & \\
SS & $63(34,4)$ & $57(40,4)$ & NS \\
SG & $83(45,4)$ & $28(19,9)$ & \\
GG & $37(20,2)$ & & \\
\hline
\end{tabular}

NS, não significante.

produtos do PCR (sequências específicas de DNA com 462 pares de bases) foram digeridos com um isômero da enzima Ball, Mscl (Gibco-BRL), resultando em produtos de 304 pares de bases (alelo 1, serina-9) ou 206 e 98 pares de bases (alelo 2, glicina-9). Bandas constantes de 47 e 111 pares de bases também eram produzidas. Antes da digestão, a efetividade do PCR era verificada através da realização de um teste em gel de agarose a $1 \%$.

\section{ANÁLISE ESTATÍSTICA}

A frequência dos alelos e a dos genótipos do grupo de pacientes e do grupo controle foram analisadas através de um teste de qui-quadrado usando o pacote estatístico STATA para Windows versão $6.0^{34}$. Através do programa $\mathrm{HWE}^{35}$ foram também analisadas as distribuições dos genótipos nos grupos controles e de pacientes e comparados com as frequências esperadas quando em equilíbrio de Hardy-Weinberg. Para a análise estatística dos trios utilizou-se o programa ETDT ${ }^{36}$.

\section{RESULTADOS}

As frequências dos genótipos dos grupos controle e de pacientes indicam que as variantes serina9-glicina estão dentro do esperado no equilíbrio de Hardy-Weinberg. Além disso não foi observada diferença estatisticamente significante nas frequências dos alelos e dos genótipos entre pacientes e controles (Tabela). A análise dos 35 trios, realizada através do programa estatístico ETDT, também não demonstrou preferência de transmissão alélica para nehuma das duas variantes polimórficas.

\section{DISCUSSÃO}

O presente estudo investigou a distribuição alélica do polimorfismo serina-9-glicina no gene que codifica o receptor dopaminérgico subtipo $D 3$, através da comparação de um grupo de pacientes com esquizofrenia e um grupo controle, além de um estudo com trios que utiliza um desenho metodológico mais cuidadoso. Esse estudo apresenta a originalidade de ser o primeiro estudo a investigar as variantes serina-9-glicina em uma amostra brasileira, e também o primeiro a utililisar a metodologia com trios (controles internos).

Poder-se-ia considerar como falso-negativos os resultados apresentados se os grupos comparados (esquizofrênicos e controles) não tivessem sido pareados segundo a origem étnica ${ }^{34}$. Além disso, o fato do grupo de pacientes e dos controles não demonstrarem desvio do equilíbrio de Hardy-Weinberg confirma que esses grupos são amostras representativas de suas populações e dessa forma reforçam os resultados analisados. Outro fato que também reforça os resultados do trabalho é que o estudo com trios foi concordante com o de caso-controle, o que ajuda a eliminar a possibilidade de interferências da questão étnica.

Apesar de estudos anteriores demonstrarem a existência de associação entre o polimorfismo em questão e esquizofrenia ${ }^{6,23,24}$, sendo confirmado por três estudos de meta-análise ${ }^{23,25,26}$, é necessário cautela na interpretação desses resultados. Há um número ainda maior de trabalhos da literatura que não confirmam esse achado ${ }^{7-22}$. É importante lembrar a existência de um viés de publicação para os trabaIhos com resultados positivos. Trabalhos com resultados negativos são mais facilmente rejeitados pelos editores das revistas ou o próprio grupo de pesquisa que realizou o estudo perde o interesse em publicá-lo por ser negativo. Em outras palavras, o número de trabalhos negativos na literatura é subestimado.

Em conclusão, a distribuição alélica observada no presente estudo sugere que não há associação alélica ou genotípica entre as variantes serina-9-glicina do gene que codifica o receptor D3 e esquizofrenia. Apesar desse polimorfismo não estar associado como fator de risco para esquizofrenia na população estudada, ele poderá estar envolvido em outras áreas correlatas como na resposta terapêutica a determinadas drogas (por exemplo, a amisulprida, um antipsicótico que age preferencialmente em receptores D2 e D3), ou na susceptibilidade para o desenvolvimento de efeitos colaterais a antipsicóticos (por exemplo, a discinesia tardia ${ }^{30}$ ).

Agradecimentos - Somos muito gratos à colaboração do Dr. Guilherme Peres Messas, Eliza Hiromi Ikenaga, Daniela Jardim e Girlene Laurita de Sena na realização desse trabalho. 


\section{REFERÊNCIAS}

1. Seeman MV. Dopamine receptor sequences: therapeutic levels of neuroleptics occupy D2 receptors, clozapine occupies D4. Neuropsychopharmacology 1992;7:261-283.

2. Sokoloff P, Giros B, Martres MP, Bouthernet ML, Schwartz JL. Molecular cloning and characterisation of a novel dopamine receptor (D3) as a novel target for neuroleptics. Nature 1990;347:146-151.

3. Buckland PR, O'Donovan MC, McGuffin P. Clozapine and sulpiride up-regulate dopamine D3 receptor mRNA levels. Neuropharmacology 1993;32:901-907.

4. Sokoloff P, Lannfelt L, Martres MP, Giros B, Bouthernet ML, Schwartz JC. The third dopamine receptor (D3) as a novel target for antipsychotics. Biochem Pharmacol 1992;43: 659-666.

5. Lannfelt L, Sokoloff P, Martres MP, et al. Amino acid substitution in the dopamine D3 receptor as a useful polymorphism for investigating psychiatric disorders. Psychiatr Genet 1992;2:249-256.

6. Crocq MA, Mant R, Asherson P, et al. Association between schizophrenia and homozygosity at the dopamine D3 receptor gene. J Med Genet 1992;29:858-860.

7. Nimgaonkar VL, Zhang XR, Caldwell JC, Ganguli R, Chakravati A. Association study of schizophrenia with dopamine $\mathrm{D} 3$ receptor gene polymorphism: probable effect of family history of schizophrenia? Am J Med Genet 1993;48:214-217.

8. Nöthen MM, Cichon P, Propping P, Fimmers R, Schwab SG, Wildenauer DB. Excess of homozygosity at the dopamine D3 receptor gene in schizophrenia not confirmed. J Med Genet 1993;30:708.

9. Jönsson E, Lannfelt L, Sokoloff P, Schwartz JC, Sedvall G. Lack of association between schizophrenia and alleles at the D3 receptor gene. Acta Psychiatr Scand 1993;87:345-349.

10. Di Bella D, Catalano M, Strukel M, Nobile M, Novelli E, Smeraldi E. Distribution of the MscI polymorphism of the dopamine D3 receptor in an Italian psychotic population. Psychiatr Genet 1994;4:39-42.

11. Laurent C, Savoye C, Samolyk D, Mallet J. Homozygosity at the dopamine D3 receptor locus is not associated with schizophrenia. J Med Genet 1994;31:260.

12. Mant R, Williams J, Ascherson P, Parfitt E, McGuffin P, Owen MJ. Relationship between homozygosity at the dopamine D3 receptor gene and schizophrenia. Am J Med Genet 1994;54:21-26.

13. Gaitonde EJ, Morris A, Sivagnanasundaram S, McKenna PJ, Hunt DM, Mollon JD. Assessment of association of D3 dopamine receptor MscI polymorphism with schizophrenia analysis of symptom ratings, family history, age at onset, and movement disorders. Am J Med Genet 1996;67:455-458.

14. Nimgaonkar VL, Sanders AR, Ganguli R, et al. Association study of schizophrenia and the dopamine D3 receptor gene locus in two independent samples. Am J Med Genet 1996;67:505-514.

15. Durany N, Thome J, Palomo A, Foley P, Riederer P, Cruz-Sanchez FF. Homozygosity at the dopamine D3 receptor gene in schizophrenic patients. Neurosci Lett 1996;220:151-154.

16. Hawi Z, McCabe U, Straub RE, et al. Examination of new and reported data of the DRD 3/ MscI polymorphism: no support proposed association with schizophrenia. Mol Psychiatry 1998;3:150-155.

17. Nanko S, Sasaki T, Fukuda R, et al. A study of the association between schizophrenia and the dopamine D3 receptor gene. Hum Genet 1993;92:336-338.
18. Yang L, Weise C, Lannfelt L, et al. No association between schizophrenia and homozygosity at the D3 dopamine receptor gene. Am Med Genet 1993;48:83-86.

19. Saha N, Tsoi WF, Low PS, Basair J, Tay JSH. Lack of association of the dopamine D3 receptor gene polymorphism (Bal I) in Chinese schizophrenic males. Psychiatr Genet 1994;4:201-204.

20. Ohara K, NakamuraY, Xie DW, et al. Polymorphisms of dopamine D2-like (D2, D3 and D4) receptors in schizophrenia. Biol Psychiatry 1996;40:1209-1217.

21. Chen CH, Liu MY, Wei FC, Koong FJ, Hwu HG, Hsiao KJ. Further evidence of no association between Ser9Gly polymorphism of dopamine D3 receptor gene and schizophrenia. Am J Med Genet 1997;2:139-145.

22. Prasad S, Dashpande SN, Bhatia T, Wood J, Nimgoankar VL, Thelma BK. Association study of schizophrenia among Indian families. Am J Med Genet 1999;88:298-300.

23. Shaikh S, Collier DA, Sham PC, et al. Allelic association between a Ser-9-Gly polymorphism in the dopamine D3 receptor gene and schizophrenia. Hum Genet 1996;97:714-719.

24. Spurlock G, Williams J, McGuffin P, et al. European Multicentre Association Study of Schizophrenia: a study of the DRD2 Ser3 and DRD3 Ser9Gly polymorphisms. Am J Med Genet 1998;81: 24-28.

25. Williams J, Spurlock G, Holmans P, et al. A meta-analysis and transmission disequilibrium study of association between the dopamine D3 receptor gene and schizophrenia. Mol Psychiatry 1998;3:141-149.

26. Dubertret C, Gorwood P, Ades J, Feingold J, Schwartz JC, Sokoloff P. Meta-analysis of DRD3 gene and schizophrenia: ethnic heterogeneity and significant association in Caucasians. Am J Med Genet 1998;81:318-322.

27. Schafetter J, Chaudhry HR, Hornik K, et al. Dopamine D3 receptor receptor gene polymorphism and response to clozapine in schizophrenia Pakastani patients. Eur Neuropsychopharmacology. 1999;10:17-20.

28. Krebs MO, Sautel F, Bourdel MC, et al. Dopamine D3 receptor gene variants and substance abuse in schizophrenia. Mol Psychiatry 1998;3:150-155.

29. Steen VM, Lovlie R, MacEwan T, McCreadie RG. Dopamine D3-receptor gene variant and susceptibility to tardive dyskinesia in schizophrenia patients. Mol Psychiatry 1997;2:139-145.

30. Basile VS, Masellis M, Badri F, et al. Association of the MscI polymorphism of the dopamine D3 receptor gene with tardive dyskinesia in schizophrenia. Neuropsychopharmacology 1999;21:17-27.

31. Shaikh S, Ball D, Craddock N, Castle D, Hunt N, Mant R.The dopamine D3 receptor gene: no association with bipolar affective disorder. J Med Genet 1993;30:308-309.

32. Dikeos DG, Papadimitriou GN, Avamoproulos D, et al. Association between the dopamine D3 receptor gene locus (DRD3) and unipolar affective disorder. Psychiatr Genet 1999;9:189-195.

33. Pilla M, Perachon S, Sautel F, et al. Selective inhibition of cocaineseeking behaviour by a partial dopamine D3 receptor agonist. Nature 1999;400:371-375.

34. Shan P. Statistics in human genetics. New York: Arnold, 1998.

35. Ott J. Utility programs for analisys of genetic linkage. New York: Columbia University, 1988.

36. Sham PC, Curtis D. Monte Carlo tests for associations between disease and alleles at highly polymorphic loci. Ann Hum Genet 1995;59:323-336. 